\title{
Nutrient Profile Study on Locally Available Small Indigenous Species (SIS) of Paschim Medinipur District of West Bengal, India
}

\author{
Prasanta Jana $^{1 *}$, Mritunjoy Paul ${ }^{1}$, Pranaysree Pravat Kumar ${ }^{2}$, \\ Sachin $\mathrm{Sahu}^{3}$ and Arka Chowdhury
}

${ }^{1}$ Fish Nutrition, Biochemistry \& Physiology Division, ICAR-Central Institute of Fisheries Education, Mumbai-400061, India

${ }^{2}$ Lamtaput Block, Koraput District, Directorate of Fisheries, Govt. of Odisha, Odisha, India

${ }^{3}$ Kawardha Block, Office of Assistant Director of Fisheries, Kabirdham, Chhattisgarh, India

${ }^{4}$ Department of Aquaculture, Faculty of Fishery Sciences, West Bengal University of Animal \& Fishery Sciences, Kolkata - 700094, India

*Corresponding author

\section{A B S T R A C T}

The proximate composition of twenty one small indigenous species (SIS) viz. Baim (Mastacembelus armatus), Bele/Bailla (Glossogobius giuris), Kholisha (Colisa fasciata), Nama Chanda (Chanda nama), Ranga Chanda (Parambassis ranga), Folui (Notopterus notopterus), Gulsha Tangra (Mystus cavasius), Guchi (Mastacembelus pancalus) Sor Punti

\section{Keywords}

Small indigenous species (SIS), Proximate composition, Nutritive value, Livelihood security, Protein hunger

Article Info

Accepted: 06 September 2018 Available Online: 10 October 2018 (Puntius sophore), Koi (Anabas testudineus), Magur (Clarias batrachus), Meni (Nandus nandus), Morala (Amblypharyngodon mola), Rani/Bou (Botia Dario), Shinghi (Heteropneustes fossilis), Taki (Channa punctatus), Tara Baim (Macrognathus aculeatus), Tangra (Mystus vittatus), Tit Punti (Puntius ticto), Shol (Channa striatus), Chitol (Notopterus chitala) available in Paschim Medinipur district of West Bengal were analyzed to assess their nutritive value. Major nutrient composition of different small indigenous fishes (SIS) like protein, lipid, moisture, ash and carbohydrate were estimated by standard methods. The crude protein content ranged between $13.86 \%$ and $19.17 \%$ with the highest protein was found in shinghi ( $H$. fossilis) and lowest in kholisha ( $C$. fasciata). Likewise, the lipid content varied from $1.18 \%$ (H. fossilis) to $5.21 \%$ (B. dario). Moisture content shows a discrepancy from $72.65 \%$ (P. sophore) to $79.71 \%$ (C. punctatus). Other nutrients such as carbohydrate content varies from $1.05 \%$ ( $N$. chitala) to $4.95 \%$ (A. testudineus) whereas, the ash content varied from $1.38 \%$ (C. batrachus) to $4.35 \%$ ( $P$. ticto). From the present study, it could be concluded that the SIS are the cheap source of quality protein and major micronutrients thereby safeguarding both nutritional and livelihood security as well as the protein hunger.

\section{Introduction}

Fish is known to be one of the cheapest sources of protein, micronutrients, essential polyunsaturated fatty acids (PUFAs) and other essential nutrients required for the normal growth and maintenance of a healthy body (Oladimeji and Sadiku, 1991; Andrew, 2001). 
Fisheries are the vital part of nutrition and food security, particularly for the rural people. It can contribute about $22 \%$ of overall animal protein consumption in developing and underdeveloped countries (Mahanty et al., 2014). Small indigenous fishes (SIS) comprise a major part of captured and cultured inland fisheries and contribute notably to the nutritional as well as livelihood security of the rural people. India is native to different freshwater fish species and about 2,246 indigenous finfish species have been recorded available till now (Lakra et al., 2010). About 765 species are reported to have from freshwater and out of this 450 species are categorized as small indigenous fishes (SIS). These small fishes (SIS) are important sources of micronutrients (especially $\mathrm{Ca}, \mathrm{Mg}$ and $\mathrm{P}$ ) and are also cheap sources of high quality animal proteins.

The small indigenous fish species (SIS) are those species which can grow maximum to a length of $25-30 \mathrm{~cm}$ in the mature or adult stage of their lifecycle (Felt et al., 1996). Because of their large inhabitants and high abundance, they comprise a significant assemblage of the total finfish population in the inland capture and culture fisheries production. People in the villages consume more SIS compared than the urban counterpart as these fishes do not have good market demand as compared to the major carps and other large fishes but plenty available from local water bodies may serve as an alternative source of quality dietary proteins in rural food and nutrition. Thus, the SIS can play a key role in preventing the widespread micronutrient deficiencies and allied diseases (Mahanty et al., 2014).

West Bengal, an eastern state of India and most of the people is very fond of different types of fishes. So a proverb is established for Bengali people is known as "Mache Vate Bengali". West Bengal is the highest per capita fish consumer among the inland states of the country with nearly $96 \%$ population being the fish eater. Though small indigenous fish species (SIS) are nutrient dense, they are often overlooked in developing nations (Roos et al., 2007). Earlier they were called as trash fish or miscellaneous fish, but nowadays, it is preferred by all classes of society and some of them are also included in organized farming as well by some landless and marginal farmers. As a result, the people with low income who are unable to afford costly species such as carp, there is an increasing demand for small indigenous fishes viz. Baim (Mastacembelus armatus), Bele/Bailla (Glossogobius giuris), Kholisha (Colisa fasciata), Nama Chanda (Chanda nama), Ranga Chanda (Parambassis ranga), Folui (Notopterus notopterus), Gulsha Tangra (Mystus cavasius), Guchi (Mastacembelus pancalus) Sor Punti (Puntius sophore), Koi (Anabas testudineus), Magur (Clarias batrachus), Meni (Nandus nandus), Morala (Amblypharyngodon mola), Rani/Bou (Botia Dario), Shinghi (Heteropneustes fossilis), Taki (Channa punctatus), Tara Baim (Macrognathus aculeatus), Tangra (Mystus vittatus), Tit Punti (Puntius ticto), Shol (Channa striatus), Chitol (Notopterus chitala) both in rural and urban domestic markets.

As far as public health is concerned, it is essential to be acquainted with the nutrient profile of the small indigenous fish species from West Bengal which could be useful to know their nutritive significance in terms of food, nutritional security and poverty alleviation. So far, very few published information is available on the proximate composition on the small indigenous fish species (SIS) of West Bengal. Considering the importance of the small indigenous fishes, the primary objective of this study was to document comprehensive nutrient profiles with a specific focus on important small indigenous species (SIS) available in Paschim Medinipur district of West Bengal. 


\section{Materials and Methods}

Fish samples of 21 different small indigenous fish species (SIS) viz. Baim (Mastacembelus armatus), Bele/Bailla (Glossogobius giuris), Kholisha (Colisa fasciata), Nama Chanda (Chanda nama), Ranga Chanda (Parambassis ranga), Folui (Notopterus notopterus), Gulsha Tangra (Mystus cavasius), Guchi (Mastacembelus pancalus) Sor Punti (Puntius sophore), Koi (Anabas testudineus), Magur (Clarias batrachus), Meni (Nandus nandus), Morala (Amblypharyngodon mola), Rani/Bou (Botia Dario), Shinghi (Heteropneustes fossilis), Taki (Channa punctatus), Tara Baim (Macrognathus aculeatus), Tangra (Mystus vittatus), Tit Punti (Puntius ticto), Shol (Channa striatus), Chitol (Notopterus chitala) were collected from different local fish markets of Paschim Medinipur district of West Bengal during the month of September 2016 to February 2018.

After collection, fish samples were thoroughly cleaned and homogenized with the help of a pestle and mortar for further use stored at $-20^{\circ}$ C.

The proximate compositions of each species were analyzed by standard 'AOAC' procedures (AOAC, 2005).

\section{Moisture}

The moisture content of the samples were determined by taking a known weight of the sample in a moisture cup and drying it in a hot air oven at $100-105^{\circ} \mathrm{C}$ till a constant weight was achieved.

The difference in weight of the sample indicated the moisture content, which was calculated by using the following formula:-

Moisture content $(\%)=($ Weight loses $/$ Weight of sample taken) $\times 100$

\section{Crude protein}

The protein content of the fish samples were determined by micro-kjeldahl method (Kelplus, pelican, India). Samples (0.5 g) were digested in digestion unit for 45 minutes by concentrated $\mathrm{H}_{2} \mathrm{SO}_{4}$. The digested sample was then distilled in distillation unit. Finally it was titrated with $0.1 \mathrm{~N} \mathrm{HCl}$ and crude protein was obtained by multiplying the total nitrogen by a conversion factor of 6.25 .

$\mathrm{N}(\%)=[($ Titration reading - blank reading $) \times$ strength of acid $\times 14 \times 100] /$ Weight of the sample $\times 1000$

Protein content $(\%)=\mathrm{N}(\%) \times 6.25$

\section{Crude lipid}

Crude lipid was estimated by Soxhlet apparatus using petroleum ether (boiling point $40-60{ }^{\circ} \mathrm{C}$ ) as the solvent. The calculation was made as follows.

$\%$ Crude lipid $=($ Weight of the residue/Sample weight) $\times 100$

\section{Total ash}

Ash is the inorganic residue obtained by burning off the organic matter of sample. Ash content was estimated by taking a known weight of sample in a silica crucible and placing it at $600{ }^{\circ} \mathrm{C}$ for 3-4 hours in a muffle furnace (Nutronics, New Delhi, India). The calculation was done as follows.

Ash content $(\%)=($ Weight of the ash/Sample weight) $\times 100$

\section{Total carbohydrate}

Total carbohydrate content was determined by calculating the difference between 100\% (accepted total value of nutritional status) and 
the sum of values of moisture, protein, fibre, lipid and ash.

Total carbohydrate $(\%)=100-(\%$ Moisture + $\% \mathrm{CP}+\% \mathrm{EE}+\%$ Total Ash)

\section{Results and Discussion}

The recent trends of global demographics show us that the world population is growing and will continue to increase. According to statistics, the world population is around seven billion today and by 2050 it will reach nine billion (FAO, 2014). A report of (FAO, 2010) forecasted the need to increase food production by over $40 \%$ by 2030 and over $70 \%$ by 2050 . With the increase in the human population, an unpredictable problem of food shortage been created in the world mainly to the acute in regards to the proteinaceous food in underdeveloped and developing world. This leads to the urge to produce more and more food to satiate the emerging billions (FAO, 2015).

Globally, it is expected that animal protein consumption will be double in the first half of this century. The strongest growth is expected in the consumption of fish. Fish as the cheapest source of easily digestible animal protein constitutes a major share in the global food basket and can meet the protein hunger, livelihood and nutritional security in the future years (FAO, 2015).

Most of the fish eaters like to eat fish because of its availability, flavours, deliciousness and excellent nutritional value. The present study demonstrated the proximate composition of some of the local small indigenous fish species (SIS) available in Paschim Medinipur district of West Bengal. The nutrient compositions of various small indigenous fishes (SIS) were shown in Table 1. The results from the present study revealed that different nutrients viz. moisture, protein, lipid, carbohydrate and ash showed variations among the twenty one collected small fish species. The muscle protein content ranged between $13.86 \%$ and $19.17 \%$ with the highest protein content in shinghi $(H$. fossilis) and morala (A. mola) while lowest in kholisha $(C$. fasciata). In fish the muscle protein content is generally remains higher than all other nutrients (Azim et al., 2012). Some authors from Bangladesh evaluated the nutrient properties of small indigenous fishes (SIS) and found that the higher protein percentage in $A$. mola (morala) than other species which is matched with the present findings (Mazumdar et al., 2008; Hossain et al., 2015). The possible differences in protein level may be due to the availability of different fish food organisms in water.

Different agro-climatic conditions in different geographical areas have a greater influence in aquatic plankton diversity, density and availability to the fishes. Comparatively, the lipid content of all the fish species ranged between $1.18 \%$ and $5.21 \%$. The highest lipid percentage was found in B. Dario, $P$. sophore, $P$. ticto and the lowest in $H$. fossilis. Sankar and Ramachandran (2001) reported that lipid content is less in smaller fishes but increases with their age and size. Hossain et al., (2015) reported that the lipid content of SIS in Bangladesh generally ranged from 1.54 to $6.28 \%$ which has a relevance to our findings. Similar findings also reported by some authors from Bangladesh (Mazumdar et al., 2008; Ahmed et al., 2012). Moisture content show a difference from $72.65 \%$ (P. sophore) to $79.71 \%$ (C. punctatus) and carbohydrate content from $1.05 \%$ (N. chitala) to $4.95 \%$ (A. testudineus). Higher levels of carbohydrate found in $A$. testudineus followed by $C$. fasciata and $C$. nama which might be due to several reproductive performances with the advance of the monsoon season. In the study, the ash content varied from $1.38 \%(C$. batrachus) to $4.35 \%$ (P. ticto). 
Table.1 Proximate composition (\% wet weight basis) of small indigenous fish species (SIS) of Paschim Medinipur district of West Bengal, India

\begin{tabular}{|c|c|c|c|c|c|c|c|}
\hline $\begin{array}{c}\text { SI } \\
\text { No. }\end{array}$ & $\begin{array}{l}\text { Local name/ } \\
\text { Common } \\
\text { name }\end{array}$ & Scientific name & Moisture (\%) & $\begin{array}{c}\text { Crude Protein } \\
(\%)\end{array}$ & $\begin{array}{l}\text { Crude Lipid } \\
\qquad(\%)\end{array}$ & Total Ash (\%) & $\begin{array}{c}\text { Total } \\
\text { Carbohydrate } \\
(\%)\end{array}$ \\
\hline 1. & Baim & Mastacembelus armatus & $75.12 \pm 0.40$ & $16.53 \pm 0.09$ & $3.02 \pm 0.13$ & $3.32 \pm 0.05$ & $1.82 \pm 0.12$ \\
\hline 2. & Bele/Bailla & Glossogobius giuris & $78.31 \pm 0.19$ & $15.61 \pm 0.12$ & $2.43 \pm 0.11$ & $2.19 \pm 0.11$ & $1.35 \pm 0.06$ \\
\hline 3. & Kholisha & Colisa fasciata & $73.18 \pm 0.17$ & $13.86 \pm 0.08$ & $4.79 \pm 0.18$ & $3.26 \pm 0.04$ & $4.85 \pm 0.09$ \\
\hline 4. & Nama Chanda & Chanda nama & $75.19 \pm 0.27$ & $14.23 \pm 0.21$ & $2.97 \pm 0.09$ & $2.88 \pm 0.06$ & $4.53 \pm 0.14$ \\
\hline 5. & Ranga Chanda & Parambassis ranga & $76.95 \pm 0.24$ & $14.04 \pm 0.24$ & $3.06 \pm 0.22$ & $3.58 \pm 0.15$ & $2.28 \pm 0.17$ \\
\hline 6. & Folui & Notopterus notopterus & $76.59 \pm 0.31$ & $16.51 \pm 0.14$ & $3.12 \pm 0.13$ & $1.99 \pm 0.09$ & $1.68 \pm 0.13$ \\
\hline 7. & Gulsha Tangra & Mystus cavasius & $75.81 \pm 0.28$ & $16.83 \pm 0.19$ & $3.81 \pm 0.16$ & $2.03 \pm 0.10$ & $1.45 \pm 0.05$ \\
\hline 8. & Guchi & Mastacembelus pancalus & $77.16 \pm 0.27$ & $17.65 \pm 0.22$ & $2.09 \pm 0.10$ & $2.01 \pm 0.11$ & $1.13 \pm 0.09$ \\
\hline 9. & Sor Punti & Puntius sophore & $72.65 \pm 0.33$ & $14.44 \pm 0.29$ & $4.19 \pm 0.12$ & $4.29 \pm 0.12$ & $4.48 \pm 0.15$ \\
\hline 10. & Koi & Anabas testudineus & $72.95 \pm 0.14$ & $16.52 \pm 0.17$ & $3.51 \pm 0.09$ & $1.91 \pm 0.04$ & $4.95 \pm 0.21$ \\
\hline 11. & Magur & Clarias batrachus & $79.03 \pm 0.12$ & $16.58 \pm 0.13$ & $1.58 \pm 0.15$ & $1.38 \pm 0.07$ & $1.34 \pm 0.07$ \\
\hline 12. & Meni & Nandus nandus & $78.18 \pm 0.19$ & $16.74 \pm 0.10$ & $1.77 \pm 0.11$ & $2.14 \pm 0.13$ & $1.15 \pm 0.13$ \\
\hline 13. & Morala & Amblypharyngodon mola & $73.68 \pm 0.09$ & $17.75 \pm 0.12$ & $1.84 \pm 0.03$ & $3.93 \pm 0.09$ & $2.79 \pm 0.17$ \\
\hline 14. & Rani/Bou & Botia dario & $72.92 \pm 0.11$ & $14.59 \pm 0.26$ & $5.21 \pm 0.17$ & $3.18 \pm 0.03$ & $3.99 \pm 0.14$ \\
\hline 15. & Shinghi & Heteropneustes fossilis & $76.21 \pm 0.21$ & $19.17 \pm 0.16$ & $1.18 \pm 0.09$ & $2.02 \pm 0.08$ & $1.37 \pm 0.09$ \\
\hline 16. & Taki & Channa punctatus & $79.71 \pm 0.22$ & $16.32 \pm 0.25$ & $1.39 \pm 0.13$ & $1.55 \pm 0.06$ & $1.07 \pm 0.03$ \\
\hline 17. & Tara Baim & Macrognathus aculeatus & $78.43 \pm 0.31$ & $17.28 \pm 0.22$ & $1.82 \pm 0.14$ & $1.47 \pm 0.10$ & $1.05 \pm 0.04$ \\
\hline 18. & Tangra & Mystus vittatus & $74.76 \pm 0.29$ & $14.92 \pm 0.29$ & $3.94 \pm 0.22$ & $4.01 \pm 0.15$ & $2.37 \pm 0.05$ \\
\hline 19. & Tit Punti & Puntius ticto & $72.84 \pm 0.33$ & $14.28 \pm 0.29$ & $4.19 \pm 0.12$ & $4.35 \pm 0.12$ & $4.29 \pm 0.15$ \\
\hline 20. & Shol & Channa striatus & $79.22 \pm 0.22$ & $16.54 \pm 0.25$ & $1.37 \pm 0.13$ & $1.67 \pm 0.06$ & $1.18 \pm 0.05$ \\
\hline 21. & Chitol & Notopterus chitala & $78.11 \pm 0.21$ & $17.09 \pm 0.19$ & $1.69 \pm 0.16$ & $2.05 \pm 0.11$ & $1.05 \pm 0.04$ \\
\hline
\end{tabular}

Mean values are represented as Mean \pm standard error obtained from three replicates 
The four small fish species such as, P. ticto, $M$. vittatus, $P$. sophore and $A$. mola contained a higher level of inorganic residue or ash content among all the small indigenous fishes (SIS). A higher level of ash leads to having a higher level of mineral in bones.

A similar observation was reported by Minar et al., (2012). Other researchers also reported the nutrient composition of small indigenous fishes (SIS) which is more or less relevance with our present findings (Hossain et al., 1999; Debnath et al., 2014; Abdullahi, 2001).

In general, this discrepancy in the nutrient content of small indigenous fishes (SIS) might be attributed to differences in species, age and size of the fish species, season of sample collection, ecological conditions and availability of fish food in water (Debnath et al., 2014; Effiong and Mohammed, 2008). Further species specific detailed studies are needed to explore the amino acid profile, fatty acid profile and mineral quantities to establish a standard nutritional database of small indigenous fishes (SIS) in India.

Several local indigenous fish species have been identified that would significantly contribute multiple nutrients intake of public health significance.

In recent decades, research largely focused on the development of aquaculture when considering the role of fish in food and nutrition security. In a nutshell, the data represented here entails that from a nutritional standpoint, species mainly from inland capture fisheries, particularly small indigenous species (SIS), hold a greater potential to micronutrient intakes of vulnerable groups in the urban population.

The results of the present study significantly expand the current knowledge on the nutritional value of the large diversity of indigenous fish species available in Paschim Medinipur district of West Bengal. Therefore, it can be recommended that small indigenous fish species (SIS) might be an excellent choice for the people of West Bengal to meet their daily dietary nutrient requirement as well as combat micronutrient deficiencies in relation to their health significance.

\section{Acknowledgement}

The authors acknowledge the Director, ICARCentral Institute of Fisheries Education, Mumbai, for providing necessary facilities for carrying out the research work.

\section{Conflict of interest}

The authors declare that they have no actual or potential conflict of interest.

\section{References}

Abdullahi, S. A., 2001. Investigation of nutritional status of Chrysichthys nigrodigitatus, Bayrus filamentous and Auchenoglanis occidentals' Family Barigdae. Journal of Aid Zone Fisheries, 1: 39-50.

Ahmed, S., Rahman, A. F. M. A., Mustafa, M. G., Hossain, M. B. and Nahar, N., 2012. Nutrient composition of indigenous and exotic fishes of rainfed waterlogged paddy fields in Lakshmipur, Bangladesh. World Journal of Zoology, 7(2): 135-140.

Andrew, A. E., 2001. Fish Processing Technology. University of IIorin press, Nigeria.pp.7-8.

AOAC, 2005. Official Methods of Analysis, $18^{\text {th }}$ ed. Association of official Analytical Chemists, Washington, DC., USA.

Azim, M. A., Islam, M. R., Hossain, M. B. and Minar, M. H., 2012. Seasonal variations in the proximate composition of Gangetic Sillago, Sillaginopsis panijus (Perciformes: Sillaginidae). Middle-East Journal of Scientific Research,11(5): 559-562.

Debnath, C., Sahoo, L., Singha, A., Yadav, G. S., Datta, M. and Ngachan, S. V., 2014. Protein and mineral compositions of some local fishes of tripura, India. Indian Journal of Hill Farming, 27(1): 210-218. 
Effiong, B. N., Mohammed, I., 2008. Effect of seasonal variation on the nutrient composition in selected fish species in Lake Kainji Nigeria. Nature and Science, 6(2): 1-5.

FAO, 2010. The state of world fisheries and aquaculture, Rome: Food and agricultural organization of the United Nations.

FAO, 2014. The State of World Fisheries and Aquaculture. FAO Fisheries and Aquaculture Department. FAO, Rome, 18.

FAO, 2015. The state of world fisheries and aquaculture, Rome: Food and agricultural organization of the United Nations.

Felts, R. A., Rajts, F. and Akhteruzzaman, M., 1996. Small indigenous fish species culture in Bangladesh (Technical Brief), IF ADEP sub-project-2. Development of inland fisheries, 41.

Hossain, M. A., Afsana, K., Azad Shah, A. K. M., 1999. Nutritional value of some small indigenous fish species (SIS) of Bangladesh. Bangladesh Journal of Fisheries Research, 3(1):77-85.

Hossain, M. N., Afroz, H., Haque, M.Z. and Begum, M., 2015. Evaluation of nutritional properties of some small indigenous fishes species in Bangladesh. International Journal of Biosciences, 6(6): 102-109.

Lakra, W. S., Sarkar, U. K., Gopalakrishnan, A. and Kathirvelpandian, A., 2010. Threatened freshwater fishes of India. National Bureau of Fish Genetic Resources.

Mahanty, A., Ganguly, S., Verma, A., Sahoo, S., Mitra, P., Paria, P., Sharma, A.P.,
Singh, B.K. and Mohanty, B.P., 2014. Nutrient profile of small indigenous fish Puntius sophore: proximate composition, amino acid, fatty acid and micronutrient profiles. National Academy Science Letters, 37(1): 39-44.

Mazumder, M. S. A., Rahman, M. M., Ahmed, A. T. A., Begum, M. and Hossain, M. A., 2008. Proximate composition of some small indigenous fish species (SIS) in Bangladesh. International Journal of sustainable crop production, 3(4): 18-23.

Minar, M. H., Adhikary, R. K., Begum, M. M., Ul-Islam, M. R. and Akter, T., 2012. Proximate composition of Hilsha (Tenualosa ilisha) in laboratory condition. Bangladesh Journal of Progressive Science and Technology, 10: 57-60.

Oladimeji, A. A. and Sadiku, S. O. E., 1991. Mineral constituents of Lates niloticus (L) Synodontis schall (Broch and Schneider) and Sarotherodon galilaeus (Trewaves) from Zaria (Nigeria) Dam. Journal of Animal Production and Research, 11: 4552.

Roos, N., Wahab, M. A., Chamnan, C. and Thilsted, S.H., 2007. The role of fish in food-based strategies to combat vitamin $\mathrm{A}$ and mineral deficiencies in developing countries. The Journal of Nutrition, 137(4): 1106-1109.

Sankar, T. V. and Ramachandran, A., 2001. Changes in biochemical composition in Indian major carps in relation to size. Fishery Technology, 38: 22-27.

\section{How to cite this article:}

Prasanta Jana, Mritunjoy Paul, Pranaysree Pravat Kumar, Sachin Sahu and Arka Chowdhury. 2018. Nutrient Profile Study on Locally Available Small Indigenous Species (SIS) of Paschim Medinipur District of West Bengal, India. Int.J.Curr.Microbiol.App.Sci. 7(10): 634-640. doi: https://doi.org/10.20546/ijcmas.2018.710.071 